\title{
Role of transaminases, CRP and LDH in COVID-19 patients with and without respiratory failure during the disease outbreak
}

\author{
Authors \\ Bianca Magro ${ }^{1^{*}}$, MD, Matteo Tacelli ${ }^{2 *}$, MD, Luisa Pasulo ${ }^{1}, \mathrm{MD}$, Massimo De Giorgio $^{1}, \mathrm{MD}$, Filippo \\ Leonardi ${ }^{1}, \mathrm{MD}$, Lucà Maria Grazia ${ }^{1}, \mathrm{MD}$, Giovanna Gaffuri ${ }^{1}, \mathrm{MD}$, Michela Triolo ${ }^{1}, \mathrm{PhD}, \mathrm{MD}$, Giampaolo \\ Mangia ${ }^{1}, \mathrm{MD}$, Domenico Nobile ${ }^{3}, \mathrm{MD}$, Marco Rizzi ${ }^{4}, \mathrm{MD}$, Fabiano Di Marco ${ }^{5}, \mathrm{PhD}$, MD, Roberto Cosentini \\ ${ }^{6}, \mathrm{MD}$, Andrea Gianatti ${ }^{7}, \mathrm{MD}$, Stefano Fagiuoli ${ }^{1}, \mathrm{MD}, \mathrm{PhD}$.
}

\author{
Affiliations \\ ${ }^{1}$ Gastroenterology, Hepatology and Liver Transplantation, Department of Medicine - Papa Giovanni, XXIII \\ Hospital, Bergamo, Italy. \\ ${ }^{2}$ Pancreato-biliary Endoscopy and EUS Division, Pancreas Translational and Clinical Research Center, San \\ Raffaele Scientific Institute IRCCS, Milan, Italy \\ ${ }^{3}$ Department of Cardiology, V.Cervello Hospital, Palermo, Italy \\ ${ }^{4}$ Infectious Diseases Unit - Papa Giovanni XXIII Hospital, Bergamo, Italy. \\ ${ }^{5}$ Dipartimento di Scienze della Salute, Università degli Studi di Milano, Respiratory Unit, Papa Giovanni XXIII \\ Hospital, Bergamo, Italy. \\ ${ }^{6}$ Emergency Department, ASST Papa Giovanni XXIII, Bergamo, Italy \\ ${ }^{7}$ Pathology Unit, ASST Papa Giovanni XXIII, Bergamo, Italy. \\ *Magro B and Tacelli M contributed equally to this paper
}

\section{Corresponding Author:}

Bianca Magro, MD

Gastroenterology, Hepatology and Liver Transplantation

Department of Medicine

Papa Giovanni, XXIII Hospital,

Piazza OMS 1, Bergamo, Italy.

Phone: +39 3925277473. Fax: +390916552276

E-mail: bianca_magro@hotmail.it

\section{CONFLICT OF INTEREST AND FINANCIAL DISCOLSURE:}

All authors have completed the ICMJE uniform disclosure form at www.icmje.org/coi_disclosure.pdf and declare: no support from any organization for the submitted work; no financial relationships with any organizations that might have an interest in the submitted work in the previous three years; no other relationships or activities that could appear to have influenced the submitted work

Authors have nothing to disclose. Guarantor of the article: Bianca Magro

\section{AUTHOR CONTRIBUTIONS:}

Bianca Magro and Matteo Tacelli designed and wrote the study. Bianca Magro collected data. Matteo Tacelli performed the statistical analysis. Stefano Fagiuoli revised the manuscript. Final approval of manuscript: all authors. The corresponding author attests that all listed authors meet authorship criteria and that no others meeting the criteria have been omitted."

\section{TRANSPARENCY DECLARATION}

The lead author Bianca Magro affirms that this manuscript is an honest, accurate, and transparent account of the study being reported; that no important aspects of the study have been omitted; and that any discrepancies from the study as planned (and, if relevant, registered) have been explained.

ETHICAL APPROVAL: The study was approved by the local Ethical Committee (Reg. Sperim. 37/20). 


\section{ABSTRACT}

BACKGROUND: Sars-Cov-2 pneumonia is a pandemic disease with high morbidity and mortality. In literature transaminases, CRP and LDH were frequently found abnormal but their role has not been clarified.

OBJECTIVES: Aim of this retrospective study is to explore the role of transaminases, CRP and LDH on short-term prognosis of hospitalized COVID-19 patients.

METHODS: patients admitted in hospital for COVID-19 were consecutively recruited. Primary endpoint: evaluate role of transaminases, CRP and LDH on disease progression (DP). Secondary endpoints: find possible risk factors for (1) mortality and (2) CPAP ventilation at day 7 . We also analyzed patients without respiratory failure at admission, also a subgroup of patients with liver disease.

RESULTS: 342 patients were included. Median age of patients was 64 years (IQR 55-74), and $35.1 \%(\mathrm{n}=120)$ was female. At multivariate analysis moderate ALT elevation at Day $1(\mathrm{p}=0.001$, OR 2,42, CI95\% 1.23-4,73) and CRP at Day 7 (p=0.001, OR 1, CI95\% 1-1,1) were predictors of DP; LDH at admission ( $\mathrm{p}=0.05$, OR 1, CI95\% 1.23-1,1) and moderate AST elevation at day 7 $(\mathrm{p}=0.04$, OR 4,5, CI95\% 1.05-19,4) were predictors of CPAP at day 7. At multivariate analysis age $(\mathrm{p}<0,001$, OR 1,12, CI95\% 1-1,2) and sex ( $\mathrm{p}=0.01$, OR 14, CI95\% 1,7-116,7) were predictors of death. Mortality rate of patients with liver disease was $25 \%(n=3 / 12)$.

CONCLUSIONS: Moderate ALT elevation at day 1 and moderate AST elevation at day 7 were respectively, predictors of DP and CPAP at day 7. For patients without respiratory failure, transaminases are not significative for anyone of our outcomes. Age, sex and CRP at day 1 are death risk factors.

Keywords: Coronavirus; COVID-19; risk factors; prognosis; mortality; italy; pandemic

\section{INTRODUCTION}

In December 2019, first cases of coronavirus disease (Covid-19) were identified in the Chinese region of Wuhan. This virus is a novel enveloped RNA beta-coronavirus, and it can lead to severe acute respiratory syndrome (SARS -CoV-2) ${ }^{1-5}$.

On $11^{\text {th }}$ march 2020 Covid-19 has been declared pandemic by World Health Organization (WHO), having infected more than 100.000 people in the world.

In a variable percentage of patients, alterations in C-reactive protein (CRP), lactate dehydrogenase (LDH) and transaminases (both alanine aminotransferase- ALT, and aspartate aminotransferase-AST) values, were shown, however only scattered data have been published to date aiming at establishing a possible role in predicting the clinical course ${ }^{1}$. One other report from $\mathrm{China}^{6}$, focused on liver injury in Covid-19, seven case series showed that $2-11 \%$ of patients had liver comorbidities and $14-53 \%$ reported abnormal ALT and AST serum values during disease. A study by Huang and colleagues ${ }^{7}$ showed that AST elevation was higher in ICU patients (62\%) compared with those who did not require ICU. The vast majority of the reported studies are from Far East countries ${ }^{1,7-11}$, where COVID-19 has spread at first, and only scattered data are available from Western countries ${ }^{12,13}$. In Italy, the first documented case of Coronavirus infection was on February $21^{\text {st }}$ and in one month an exponential growth in contagions and deaths has been observed, reaching 
respectively over 90.000 documented cases and over 10.000 demises $^{14,15}$. One of the cities epicenters of epidemic COVID-19 in Italy was Bergamo, and its hospital is one of the centers with most admitted infected patients ${ }^{16}$.

Aim of this retrospective study is to explore the possible clinical role of transaminases and CRP in defining the prognosis of hospitalized COVID-19 patients, both with liver disease and not.

\section{METHODS}

\section{Patients}

We retrospectively analyzed 343 consecutive patients admitted at HPG23 for COVID-19 infection, in the period of time ranging from February $22^{\text {th }}$ and March $30^{\text {th }} 2020$

Inclusion criteria were: age $>18$ years; a SarsCov-2 nasal swab positive.

We focused on all those lab tests that were routinely performed at the Emergency Department that are often increased in these patients (transaminases, CRP and LDH)

Exclusion criteria were: outpatients with no need of hospital admission, patients requiring ventilatory support in ICU at admission, patients without information on the clinical course at 7 days.

We considered two subgroups according with the presence or the absence of respiratory failure ad admission.

We also identified patients with liver disease and we analyzed clinical and laboratory findings.

Liver disease was defined by medical history of chronic liver disease

Respiratory failure was defined by the presence of any of the following conditions: i) significantly increased respiration rate (RR): $\mathrm{RR}>30$ times/minute; ii) hypoxia: oxygen saturation (resting state) $<-93 \%$; iii) blood gas analysis: partial pressure of oxygen/fraction of inspired oxygen $(\mathrm{PaO} 2) / \mathrm{FiO} 2)<300 \mathrm{mmHg}$ (millimeters of Mercury). ${ }^{17}$

Cardiopathy was defined as medical history of coronary artery disease.

\section{Data collection}

Medical history, clinical symptoms and laboratory findings were extracted from electronic medical records at the moment of the hospitalization and at day 7 . The paper was written according to STROBE recommendations (Supplementary Table 1$)^{18}$.

\section{Outcome}

Primary endpoint was to evaluate the role of transaminases, CRP and LDH at admission and after one week on disease progression. We defined disease progression as the worsening in ventilation support after seven days from hospitalization.

The secondary endpoints were to evaluate possible risk factors for: (1) mortality and (2) need of CPAP (Continuous Positive Airway Pressure) at day 7.

We divided transaminases elevation in mild $(<$ 2 UNR) and moderate ( $>2$ UNR), according to American College of Gastroenterology definition ${ }^{19}$

LDH, CRP were defined significantly increased or decreased if there was an a $\pm 50 \%$ difference in the absolute value at day 7 compared with the admission value.

The onset of clinical history, comorbidities and treatments were recorded. Laboratory tests consisted of a complete blood count, creatinine, c-reactive protein, lactate dehydrogenase, assessment of liver function, electrolytes.

We searched for possible predictors of disease progression at univariate analysis considering the subsequent variables: age, sex, liver disease, symptoms of presentation (fever, respiratory, neurological, gastrointestinal ones), LDH/AST/ALT/CRP values at admission and after 7 days, comorbidities (arterial hypertension, cardiopathies, rheumatological/neurological/nephrological/re spiratory ones, obesity, use of ARBs).

\section{Statistical analysis:}

Data for continuous variables are presented as mean and standard deviation (SD) or as median and interquartile range, and data for categorical variables as frequency and percentage. Differences between continuous data were analyzed by Student $t$ test and Chi square test 
was used for dichotomous or categorical variables. The univariate and multivariate logistic and linear regression model were used to assess the independent factors of disease progression. Variables with a $\mathrm{p}$ value $<0.1$ at univariate analysis were included in the multivariate model. A p-value $<0.05$ was considered statistically significant. Statistical analysis was conducted using MedCalc
Statistical Software Version 12.5.0 (MedCalc Software LTD, Ostend, Belgium).

\section{RESULTS}

Baseline characteristics

Baseline characteristics of the 342 patients are reported in Table 1 according to the presence $(n=135)$ or the absence $(n=207)$ of respiratory failure at admission.

Table 1: Baseline features of patients according to the presence of respiratory failure at admission

\begin{tabular}{|c|c|c|c|}
\hline & Total $(n=342)$ & $\begin{array}{c}\text { Respiratory failure } \\
(n=135)\end{array}$ & $\begin{array}{c}\text { No Respiratory failure } \\
(n=207)\end{array}$ \\
\hline Age median & $64(55-74)$ & $68(58,25-74)$ & $63(51-74)$ \\
\hline Female $n(\%)$ & $120(35,1)$ & $24(33,3)$ & $75(36,2)$ \\
\hline $\begin{array}{l}\text { Liver disease (LD) } \\
n(\%)\end{array}$ & $12(3.5)$ & $9(6.7)$ & $3(1.5)$ \\
\hline $\begin{array}{l}\text { Hypertension } \\
n(\%)\end{array}$ & $152(44.7)$ & $64(47.4)$ & 88 (42.9) \\
\hline Diabetes $n(\%)$ & $47(13.8)$ & $25(18.5)$ & $25(12.2)$ \\
\hline Obesity n (\%) & $36(11.8)$ & $10(7.4)$ & $26(15.2)$ \\
\hline Fever $n(\%)$ & $288(84.5)$ & 129 (95.6) & 159 (77.6) \\
\hline $\begin{array}{l}\text { Gastrointestinal } \\
\text { symptoms } n(\%)\end{array}$ & $41(12)$ & 17 (12.6) & $24(11.7)$ \\
\hline $\begin{array}{l}\text { Respiratory } \\
\text { symptoms } n(\%)\end{array}$ & $187(54.8)$ & $126(93.3)$ & $61(29.6)$ \\
\hline $\begin{array}{l}\text { Neurological } \\
\text { symptoms } n(\%)\end{array}$ & $10(2.9)$ & $10(7.4)$ & 0 \\
\hline $\begin{array}{l}\text { Cardiological } \\
\text { comorbidities } n \\
(\%)\end{array}$ & $47(13)$ & $28(20.7)$ & $19(9.3)$ \\
\hline $\begin{array}{l}\text { Oncological } \\
\text { comorbidities } n \\
(\%)\end{array}$ & $20(5.9)$ & $7(5.2)$ & $13(6.3)$ \\
\hline $\begin{array}{l}\text { Pneumological } \\
\text { comorbidities } n \\
(\%)\end{array}$ & $25(7.4)$ & $14(10.4)$ & $11(5.4)$ \\
\hline $\begin{array}{l}\text { Nephrological } \\
\text { comorbidities } n \\
(\%)\end{array}$ & $21(6.2)$ & $4(3)$ & $17(8.3)$ \\
\hline $\begin{array}{l}\text { Reumathological } \\
\text { comorbidities } n \\
\text { (\%) }\end{array}$ & $10(2.9)$ & $3(2.2)$ & $7(3.4)$ \\
\hline
\end{tabular}


Median age of patients was 64 years (IQR 55$74)$, and $35.1 \%(n=120)$ was female.

The most common symptoms were respiratory ones $(54,8 \% ; n=187)$.

In the cohort of patients without respiratory failure at admission median age was 63 (IQR 51-74), and 36,2 \% was female. The most common symptom was fever $(77,2 \%, \mathrm{n}=159)$.

Among comorbidities the most represented was hypertension $(44,7 \% ; \mathrm{n}=152)$ followed by diabetes $(13,8 \%$; $\mathrm{n}=47)$.

The $17.2 \%$ of the population was in treatment with Angiotensin Receptor Blockers (ARBs) and/or Angiotensin Converting Enzyme inhibitors (ACE-inhibitors).

All patients were treated with lopinavirritonavir $(400 \mathrm{mg}$ and $100 \mathrm{mg}$, orally twice daily) and Hydroxychloroquine (200 mg, orally twice daily), that was the only treatment available during the disease outbreak.

\section{Laboratory findings}

Data on transaminases, CRP and LDH are shown in Supplementary table 2.

Median value at Day 1 of serum AST and ALT were respectively $41 \mathrm{U} / \mathrm{L}$ (IQR 26-63,25) and $34 \mathrm{U} / \mathrm{L}$ (IQR 23-58) and they were above the upper normal range in $50.6 \%(n=163)$ and $40.7 \%(n=129)$ of cases. After one week of hospitalization AST and ALT median values were respectively $40 \mathrm{U} / \mathrm{L}$ (IQR 25-62) and 42,5 U/L (IQR 26-71). The difference between ALT at day 1 and at day 7 was statistically significant $(\mathrm{p}=0.002)$

Moreover, in the subgroups of patients with and without respiratory failure we found statistically significant differences in CRP $(\mathrm{p}<0.001)$, AST $(\mathrm{p}<0.001)$, ALT $(\mathrm{p}=0.03)$ and LDH $(\mathrm{p}<0.001)$ at admission, and in CRP $(\mathrm{p}=0.02)$, AST $(\mathrm{p}=0.001)$ and LDH $(\mathrm{p}<0.001)$ at day 7.

Classifying patients according with transaminases values, we found that mild and moderate ALT elevation was present respectively in $35,9 \% \quad(n=105)$ and $18,2 \%$ $(n=53)$ of cases. Similarly, mild and moderate AST elevation was observed in $33,4 \%(n=97)$ and $14,5 \% \quad(n=42)$ of patients. In $41,9 \%$ $(n=133)$ patients' transaminases were both normal, while the moderate elevation of both AST and ALT values was present in $9,1 \%$ of patients $(n=29)$.

Mild and moderate AST and ALT elevation were reported in Supplementary table 3 according to the presence of respiratory failure. CRP median value at day 1 was $7 \mathrm{mg} / \mathrm{dl}$ (2-14) and at day $715 \mathrm{mg} / \mathrm{dl}(5-27,25)$

LDH median value at day 1 was 329 (260,5$463)$ and at day $7302 \mathrm{U} / \mathrm{L}(242-400)$

\section{Patients with liver disease}

Among the patients included in our study, $3.5 \%$ $(n=12 / 342)$ were affected by a liver disease: 3 chronic viral hepatitis, 4 cirrhosis alcohol related, 5 nonalcoholic fatty liver disease/ nonalcoholic steatohepatitis. Median age was 64 years (IQR 56-74) and $16.7 \%(n=2 / 12)$ were female. Features are shown in Supplementary Table 4. At admission 3 patients did not need oxygen ventilation, 5 patients were on nasal cannulas/Venturi Mask (41.7\%) and 4 patients were on reservoir mask (33.3\%).

Median value at hospital admission of serum AST and ALT were respectively $45 \mathrm{U} / \mathrm{L}$ (IQR 27-63.5) and $33 \mathrm{U} / \mathrm{L}$ (IQR 24-54). Mortality rate was $25 \%(\mathrm{n}=3 / 12)$.

\section{Disease progression}

Pulmonary disease progression was observed in $133 / 342$ patients $(38.9 \%)$ with an increased need in ventilation support: one hundred fourteen patients needed to begin oxygen ventilation (81 patients to nasal cannula/Venturi mask, 11 to Reservoir mask and 22 to CPAP), 17 from nasal cannula/Venturi mask (15 to Reservoir mask and 2 to CPAP) and 2 from Reservoir mask to CPAP.

The variables resulted significative at univariate analysis for DP were sex, ALT at day $1>2$ UNR; CRP value at day 7 and respiratory failure at admission.

In the subgroup analysis of patients without respiratory failure the significative variables at univariate analysis were: sex, fever, LDH at day7, moderate ALT elevation at day 1, CRP value at day 1 and at day 7 
At multivariate analysis moderate ALT elevation at Day $1(\mathrm{p}=0.001$, OR $2,42, \mathrm{CI} 95 \%$ $1.23-4,73)$ and CRP at Day $7(\mathrm{p}=0.001$, OR 1 , CI95\% 1-1,1) were predictors of disease progression. (Table 2)

We also analyzed patients without respiratory failure and at multivariate analysis LDH at Day 7 was the only predictor of DP ( $\mathrm{p}=0.01$, OR 1 , CI95\% 1-1,1)

\section{CPAP at day 7}

During the course of hospitalization 27/342 (7.9\%) patients needed CPAP.

Possible predictors for CPAP, at univariate analysis, were LDH, AST at day 7> 2 UNR,
CRP at day 7, while for patients without respiratory failure $\mathrm{LDH}, \mathrm{CRP}$ at day 7 and respiratory symptoms at admission were significative

We analyzed in multivariate analysis predictors of CPAP. (Table 2) (Table 3)

In the first group $\mathrm{LDH}$ at admission $(\mathrm{p}=0.05$, OR 1, CI95\% 1.23-1,1) and moderate AST elevation at day $7(\mathrm{p}=0.04$, OR $4,5, \mathrm{CI} 95 \%$ $1.05-19,4$ ) were predictors. (Table 2)

In the second group respiratory symptoms at admission ( $\mathrm{p}=0.02$, OR 6,62, CI95\% 1.44$30,27)$, and $\mathrm{LDH}$ at Day 7 ( $\mathrm{p}=0,01$, OR 1,1 , CI95\% $1-1,1$ and CRP at day $7(\mathrm{p}=0.05$, OR $1,1, \mathrm{CI} 95 \%$ 0,9-1) were significative

Table 2: Multivariate analysis for DP, death and CPAP at day 7 in the entire cohort of patients

$\begin{array}{llll}\text { Variable } & P & P & \text { Odds ratio }\end{array}$

\begin{tabular}{|c|c|c|c|c|}
\hline & & $\begin{array}{c}\text { (univariate } \\
\text { analysis) }\end{array}$ & $\begin{array}{c}\text { (multivariate } \\
\text { analysis) }\end{array}$ & (СI95\%) \\
\hline \multirow{3}{*}{$\begin{array}{l}\text { Disease } \\
\text { Progression }\end{array}$} & Sex & 0.045 & 0,28 & \\
\hline & ALT at day $1>2 \mathrm{UNR}$ & 0.01 & $\mathbf{0 , 0 1}$ & $2,42(1,23-4,73)$ \\
\hline & CRP at day 7 & $<0.001$ & $\mathbf{0 , 0 0 7}$ & $1,1(1-1,1)$ \\
\hline \multirow{9}{*}{ Death } & Age & $<0.001$ & $<0.001$ & $1,1(1,01-1,2)$ \\
\hline & Sex & 0.003 & 0.01 & $14,22(1,7-116,73)$ \\
\hline & LDH at day 1 & $<0.001$ & 0.12 & \\
\hline & AST at day $1>2 \mathrm{UNR}$ & 0.02 & 0.23 & \\
\hline & $\begin{array}{l}\text { Nephrological } \\
\text { comorbidities }\end{array}$ & 0.02 & 0.22 & \\
\hline & $\begin{array}{l}\text { Cardiological } \\
\text { comorbidities }\end{array}$ & $<0.001$ & 0.10 & \\
\hline & $\begin{array}{l}\text { Pneumological } \\
\text { comorbidities }\end{array}$ & 0.02 & 0.69 & \\
\hline & Treatment with sartans & 0.04 & 0,19 & \\
\hline & CRP at day 1 & $<0.001$ & 0.01 & \\
\hline \multirow{3}{*}{$\begin{array}{l}\text { CPAP at } \\
\text { day } 7\end{array}$} & LDH at day 7 & $<0.001$ & 0,002 & $1,1(1-1,1)$ \\
\hline & CRP at day 7 & $<0.001$ & $<0.001$ & $1.07(1.01-1.1)$ \\
\hline & AST at day $7>2$ UNR & 0.01 & 0,09 & \\
\hline
\end{tabular}


Table 3: Multivariate analysis for DP, death and CPAP at day 7 in the subgroup of patients without respiratory failure

\begin{tabular}{|c|c|c|c|}
\hline & Total $(n=342)$ & $\begin{array}{c}\text { Respiratory failure } \\
(n=135)\end{array}$ & $\begin{array}{c}\text { No Respiratory failure } \\
(n=207)\end{array}$ \\
\hline Age median & $64(55-74)$ & $68(58,25-74)$ & $63(51-74)$ \\
\hline Female $n(\%)$ & $120(35,1)$ & $24(33,3)$ & $75(36,2)$ \\
\hline $\begin{array}{l}\text { Liver disease (LD) } \\
n(\%)\end{array}$ & $12(3.5)$ & $9(6.7)$ & $3(1.5)$ \\
\hline $\begin{array}{l}\text { Hypertension } \\
n(\%)\end{array}$ & $152(44.7)$ & $64(47.4)$ & $88(42.9)$ \\
\hline Diabetes $n(\%)$ & $47(13.8)$ & $25(18.5)$ & $25(12.2)$ \\
\hline Obesity $n(\%)$ & $36(11.8)$ & $10(7.4)$ & $26(15.2)$ \\
\hline Fever $n(\%)$ & $288(84.5)$ & $129(95.6)$ & $159(77.6)$ \\
\hline $\begin{array}{l}\text { Gastrointestinal } \\
\text { symptoms } n(\%)\end{array}$ & $41(12)$ & $17(12.6)$ & $24(11.7)$ \\
\hline $\begin{array}{l}\text { Respiratory } \\
\text { symptoms } n(\%)\end{array}$ & $187(54.8)$ & $126(93.3)$ & $61(29.6)$ \\
\hline $\begin{array}{l}\text { Neurological } \\
\text { symptoms } n(\%)\end{array}$ & $10(2.9)$ & $10(7.4)$ & 0 \\
\hline $\begin{array}{l}\text { Cardiological } \\
\text { comorbidities } n \\
(\%)\end{array}$ & $47(13)$ & $28(20.7)$ & $19(9.3)$ \\
\hline $\begin{array}{l}\text { Oncological } \\
\text { comorbidities } n \\
(\%)\end{array}$ & $20(5.9)$ & $7(5.2)$ & $13(6.3)$ \\
\hline $\begin{array}{l}\text { Pneumological } \\
\text { comorbidities } n \\
(\%)\end{array}$ & $25(7.4)$ & $14(10.4)$ & $11(5.4)$ \\
\hline $\begin{array}{l}\text { Nephrological } \\
\text { comorbidities } n \\
(\%)\end{array}$ & $21(6.2)$ & $4(3)$ & $17(8.3)$ \\
\hline $\begin{array}{l}\text { Reumathological } \\
\text { comorbidities } n \\
\text { (\%) }\end{array}$ & $10(2.9)$ & $3(2.2)$ & $7(3.4)$ \\
\hline
\end{tabular}

\section{Death}

In our cohort death events within the first 7 days were observed in $14.9 \%(n=51)$ of the cases, 43 males $(84.3 \%)$ and 8 females $(10 \%$, $\mathrm{p}=0.002)$. Median age of the patients who died was 75 years (IQR 70 - 82).

At multivariate analysis age $(\mathrm{p}<0,001$, OR 1,12 , CI95\% 1-1,2) and sex $(\mathrm{p}=0.01$, OR 14, CI95\% 1,7-116,7) (Table 2) were predictors of death.

In the subgroup of patients without respiratory failure age ( $\mathrm{p}<0,003$, OR 1,14 CI95\% 1-1,22) and CRP at day $1(\mathrm{p}=0,01, \mathrm{OR} 1,1, \mathrm{CI} 95 \% 1-$ $1,2)$ were significative.

\section{DISCUSSION}

The rapid spread of the Covid-19 infection and the rapidity of respiratory deterioration hamper the possibility to meet the needs of many critically ill patients, simultaneously presenting in the Emergency Department ${ }^{20,21}$.

Our study was specifically oriented on the identification of potential risk factors of disease progression or death, with a particular focus on transaminases serum levels. Another goal was 
to compare the two subgroups of admitted Covid-19 patients, with and without respiratory failure. In literature some studies considering the possible role of transaminases elevation in Covid-19 infection have been reported 22,23,2425

All these studies are burdened by some biases as the fact that in most cases patients were selected according to the gravity of their disease or that transaminases values were not adjusted for other possible competitive factors. As described in study conducted in China ${ }^{1}$, which reported serum transaminases elevation rate of $14-53 \%$, we also found that AST and ALT were abnormal in approximatively half of patients (respectively $50.8 \%$ and $54.1 \%$ ) . In this Chinese study, it is also reported a higher rate of abnormal transaminases in ICU patients, with an increasing trend during hospitalization. Another important recent study of more than 5000 patients showed that AST increase, especially in severe patients, was associated with the highest mortality risk. ${ }^{26}$

We differentiated patients according to the grade of transaminases elevation, AST and ALT moderate elevation at day 1 and at day 7 were respectively $15,6 \%-18,2 \%$ and $14,5 \%$ $23,1 \%$. Moreover, we also analyzed patients according to the presence of respiratory failure at admission.

In our analysis we found at multivariate analysis that moderate AST elevation at day 7 is a predictor of CPAP ventilation for patients with respiratory failure at admission $(\mathrm{p}=0,04$, OR 4,52)

Also, in a large cohort of COVID-19 patients $(n=551)$, AST elevation was associated with higher mortality, in this case authors suggested as possible etiology the ischemic injury. ${ }^{27}$

Wang et al in their study reported that a possible factor for the liver injury occurrence in Covid-19 patients could be the high levels of positive end expiratory pressure that can cause hepatic congestion by increasing right atrial pressure and impeding venous return. ${ }^{28}$

Moreover, we individuated as predictor of DP, at multivariate analysis, moderate ALT elevation at day $1(\mathrm{p}=0,001$ OR 2,43$)$.

Regarding patients without respiratory failure at admission transaminases elevation at day 1 and/or at day 7 was not a predictor for anyone of the outcomes considered in our study.

If we consider Sars-Cov-2 pneumonia as a trigger for a huge inflammatory response, we can suppose that in patients with a more severe disease (respiratory failure at admission) transaminases elevation could be considered as a surrogate of a more severe systemic disease, but with the limited availability of clinical and laboratory data it is difficult to be conclusive.

All patients hospitalized in our hospital, during the "first wave" of the pandemic, were in treatment with ritonavir/lopinavir from day to of hospitalization, in this case drug induced liver injury (DILI) is not likely for the occurrence time of hypertransaminasemia, but for the certain diagnosis hepatic biopsy was necessary.

Another possible cause of transaminases elevation could be related also to the viral infection of cholangiocytes through $\mathrm{ACE} 2^{29}$ or to the systemic inflammatory cytokine storm that could involve liver too. ${ }^{30,31}$ Furthermore, in the small subgroup of patients with a baseline liver disease, transaminases and CRP values were not significantly different respect to general population.

Regarding patients with pre-existing liver disease, we found the $3.5 \%$ affected by LD. In this recent meta-analysis prevalence of liver disease in Covid-19 patients was very low (3\%), but it was conducted on 2034 patients, the most common cause was viral chronic hepatitis (HCV or HBV).$^{32}$ In our findings preexisting liver disease was not found to be a predictive factor for mortality and disease progression, but we should not consider these results as conclusive because of the small sample size.

From our data, to underline role of the inflammatory response, CRP at day 7 emerged as predictor of $\mathrm{DP}(\mathrm{p}=0,001 \mathrm{OR} 1,1)$ and it was also a predictor for CPAP ventilation at day 7 $(\mathrm{p}=0,05$ OR 1,1$)$ in the subgroup of patients without respiratory failure at multivariate analysis.

Also, in another recent study CRP and transaminases emerged as risk factors of mortality in COVID-19 hospitalized patients. ${ }^{33}$ 
Since CRP is elevated in most inflammatory conditions, so as pneumonia ${ }^{34}$, its prognostic role need to be carefully weighted. Indeed, with such awareness, regular monitoring of CRP values during hospitalization should be carried out in relation to clinical features.

Other studies put their attention on LDH as possible risk factor of more severe disease ${ }^{35}$

Our data showed that LDH at day 7 is predictor of DP and CPAP ventilation for patients without respiratory failure $(\mathrm{p}=0,01$; OR 1,1 $\mathrm{p}=0,001$; OR 1 ), while $\mathrm{LDH}$ at day 1 is a predictor of CPAP for patients presenting respiratory failure at admission $(\mathrm{p}=0,05 ; \mathrm{OR} 1)$. $\mathrm{LDH}$ is released from cells upon damage of cytoplasmic membrane and its levels might reflect tissue necrosis related to immune hyperactivity, which thus relates to poor outcome ${ }^{36}$

While focusing on death, mortality rate $(14,9 \%)$ was higher compared to other studies from the Far East (3\%), likely due to differences in the study populations: not only our population was older but, once more, outpatients were not included in our series.

At multivariate analysis we found age $(\mathrm{p}<0,001$ OR 1,12) and sex ( $\mathrm{p}=0,01$ OR 14,22) as predictors, while for patients without respiratory failure age $(\mathrm{p}=0,001 \mathrm{OR} 1,13)$ and CRP at day $1 \quad(p=0,01$ OR 1,14) were significative

In the literature gender had already been studied in Covid-19 patients, showing the same mortality but a less severe disease in females. In fact, sex hormones can affect the inflammatory modulation during infection, with estrogens promoting both innate and adaptive immunity having a suppressive effect on immune function 37,38 ,
No differences were found in outcomes after excluding patients with pre-existing liver disease.

This study presents some intrinsic limits such as the relatively small sample size, the retrospective design and the short initial duration of patient observation. Especially regarding this last point, a seven days observation, can define the short-term outcome, but may underestimate both long term disease progression and mortality. In view of the rapid deterioration of respiratory function, the large number of infected patients and the limited available data that we can use to manage this pandemic disease, these data suggest which could be biochemical and clinical variables to consider during the hospitalization of Covid-19 patients with pneumonia. Therefore, our study can only be referred as the picture of mortality rate among hospitalized patients with COVID-19 in Italy.

\section{CONCLUSIONS}

In conclusion we identified possible risk factors of a more severe disease, especially we found that almost all patients had a mild transaminases alteration, but it is the moderate ALT elevation at day 1 and the moderate AST elevation at day 7 respectively, predictors of DP and CPAP at day 7.

Moreover, for patients without respiratory failure, transaminases are not significative for anyone of our outcomes and it is the first study to analyze also this subgroup of patients.

Regarding mortality, transaminases are not predictors but we found age, sex and CRP at day 1 as possible risk factors. 


\section{BIBLIOGRAPHY}

1. Guan W, Ni Z, Hu Y, et al. Clinical Characteristics of Coronavirus Disease 2019 in China. New England Journal of Medicine. Published online February 28, 2020:NEJMoa2002032. doi:10.1056/NEJMoa2002032

2. Zhu N, Zhang D, Wang W, et al. A novel coronavirus from patients with pneumonia in China, 2019. New England Journal of Medicine. 2020;382(8):727-733. doi:10.1056/NEJMoa2001017

3. Wu F, Zhao S, Yu B, et al. A new coronavirus associated with human respiratory disease in China. Nature. 2020;579(7798):265269. doi:10.1038/s41586-020-2008-3

4. $\quad \mathrm{Lu} \mathrm{R}$, Zhao X, Li J, et al. Genomic characterisation and epidemiology of 2019 novel coronavirus: implications for virus origins and receptor binding. The Lancet. 2020;395(10224):565-574.

doi:10.1016/S0140-6736(20)30251-8

5. Phan LT, Nguyen T V., Luong QC, et al. Importation and human-to-human transmission of a novel coronavirus in Vietnam. New England Journal of Medicine. 2020;382(9):872-874.

doi:10.1056/NEJMc2001272

6. Zhang C, Shi L, Wang F. Liver injury in COVID-19 : management and challenges. The Lancet. 2020;10(20):2019-2021. doi:10.1016/S2468-1253(20)30057-1

7. Huang C, Wang Y, Li X, et al. Clinical features of patients infected with 2019 novel coronavirus in Wuhan, China. The Lancet. 2020;395(10223):497-506.

doi:10.1016/S0140-6736(20)30183-5

8. Zhang J jin, Dong X, Cao Y yuan, et al. Clinical characteristics of 140 patients infected with SARS-CoV-2 in Wuhan, China. Allergy: European Journal of Allergy and Clinical Immunology. Published online 2020. doi:10.1111/all.14238

9. Zhou F, Yu T, Du R, et al. Clinical course and risk factors for mortality of adult inpatients with COVID-19 in Wuhan, China: a retrospective cohort study. The Lancet. 2020;395(10229):1054-1062. doi:10.1016/S0140-6736(20)30566-3
10. Li L, Huang T, Wang Y, et al. 2019 novel coronavirus patients' clinical characteristics, discharge rate and fatality rate of meta-analysis. Journal of Medical Virology. Published online March 2020:jmv.25757. doi:10.1002/jmv.25757

11. Yang $\mathrm{X}, \mathrm{Yu} \mathrm{Y}, \mathrm{Xu} \mathrm{J}$, et al. Clinical course and outcomes of critically ill patients with SARS-CoV-2 pneumonia in Wuhan, China: a single-centered, retrospective, observational study. The Lancet Respiratory Medicine. 2020;0(0). doi:10.1016/S22132600(20)30079-5

12. Rothe C, Schunk M, Sothmann P, et al. Transmission of 2019-NCOV infection from an asymptomatic contact in Germany. New England Journal of Medicine. 2020;382(10):970-971. doi:10.1056/NEJMc2001468

13. Holshue ML, DeBolt C, Lindquist S, et al. First Case of 2019 Novel Coronavirus in the United States. New England Journal of Medicine. 2020;382(10):929-936. doi:10.1056/NEJMoa2001191

14. Grasselli G, Pesenti A, Cecconi M. Critical Care Utilization for the COVID-19 Outbreak in Lombardy, Italy. JAMA. Published online March 2020. doi:10.1001/jama.2020.4031

15. Spina S, Marrazzo F, Migliari $M$, Stucchi R, Sforza A, Fumagalli R. The response of Milan's Emergency Medical System to the COVID-19 outbreak in Italy. The Lancet. 2020;395(10227):e49-e50. doi:10.1016/S0140-6736(20)30493-1

16. Nacoti M, Ciocca A, Giupponi A, Brambillasca P. At the Epicenter of the Covid19 Pandemic and Humanitarian Crises in Italy: Changing Perspectives on Preparation and Mitigation. NEJM Catalyst: Innovations in Care Delivery. 2020;(Figure 1):1-5. doi:10.1056/CAT.20.0080

17. Lopes Ferreira F, Peres Bota D, Bross A, Mélot C, Vincent JL. Serial evaluation of the SOFA score to predict outcome in critically ill patients. Journal of the American Medical Association. 2001;286(14):1754-1758. doi:10.1001/jama.286.14.1754 
18. von Elm E, Altman DG, Egger M, Pocock SJ, Gøtzsche PC, Vandenbroucke JP. The Strengthening the Reporting of Observational Studies in Epidemiology (STROBE) statement: guidelines for reporting observational studies. Lancet. 2007;370(9596):1453-1457. doi:10.1016/S0140-6736(07)61602-X

19. Kwo PY, Cohen SM, Lim JK. ACG Clinical Guideline: Evaluation of Abnormal Liver Chemistries. American Journal of Gastroenterology. 2017;112(1):18-35. doi:10.1038/ajg.2016.517

20. Daugherty Biddison L, Berkowitz KA, Courtney B, et al. Ethical considerations: Care of the critically ill and injured during pandemics and disasters: CHEST consensus statement. Chest. 2014;146(4):e145S-e155S. doi:10.1378/chest.14-0742

21. Sandrock CE. Care of the critically ill and injured during pandemics and disasters: Groundbreaking results from the task force on mass critical care. Chest. 2014;146(4):881-883. doi:10.1378/chest.14-1900

22. Kumar VCS, Harne PS, Mukherjee S, et al. Transaminitis is an indicator of mortality in patients with COVID-19: A retrospective cohort study. World Journal of Hepatology. 2020;12(9):619-627.

doi:10.4254/WJH.V12.I9.619

23. Cai Q, Huang D, Yu H, et al. COVID19: Abnormal liver function tests. Journal of Hepatology. 2020;73(3):566-574. doi:10.1016/j.jhep.2020.04.006

24. Medetalibeyoglu A, Catma Y, Senkal $\mathrm{N}$, et al. The effect of liver test abnormalities on the prognosis of COVID-19. Annals of Hepatology. 2020;19(6):614-621. doi:10.1016/j.aohep.2020.08.068

25. Jalan R, Fernandez J, Wiest R, et al. Bacterial infections in cirrhosis: A position statement based on the EASL Special Conference 2013. Journal of Hepatology. 2014;60(6):1310-1324.

doi:10.1016/j.jhep.2014.01.024

26. Lei F, Liu Y, Zhou F, et al. Longitudinal association between markers of liver injury and mortality in COVID-19 in China. Hepatology.
Published online May 2020:hep.31301. doi:10.1002/hep.31301

27. Harsh G, Farah H, Kawish G, Pooja S, Daly $t \mathrm{AK}$ and HJ. The liver in COVID-19: prevalence, patterns, predictors, and impact on outcomes of liver test abnormalities - PubMed. 28. Wang D, Hu B, Hu C, et al. Clinical Characteristics of 138 Hospitalized Patients with 2019 Novel Coronavirus-Infected Pneumonia in Wuhan, China. JAMA - Journal of the American Medical Association. 2020;323(11):1061-1069.

doi:10.1001/jama.2020.1585

29. Chai X, Hu L, Zhang Y, et al. Specific ACE2 Expression in Cholangiocytes May Cause Liver Damage After 2019-nCoV Infection. bioRxiv. Published online February 2020:2020.02.03.931766.

doi:10.1101/2020.02.03.931766

30. Xu L, Liu J, Lu M, Yang D, Zheng X. Liver injury during highly pathogenic human coronavirus infections. Liver International. Published online March 2020:liv.14435. doi:10.1111/liv.14435

31. Zhang C, Shi L, Wang F. Liver injury in COVID-19: management and challenges. The Lancet. 2020;10(20):2019-2021. doi:10.1016/S2468-1253(20)30057-1

32. Mantovani A, Beatrice G, Dalbeni A. Coronavirus disease 2019 and prevalence of chronic liver disease: A meta-analysis. Sun J, ed. Liver International. Published online April 2020:liv.14465. doi:10.1111/liv.14465

33. Ashktorab H, Pizuorno A, Aduli F, Laiyemo AO, Oskrochi G, Brim H. Elevated liver enzymes, ferritin, CRP, D-dimer, and age are predictive markers of outcomes among Covid-19 African Americans and Hispanic patients. Gastroenterology. Published online March 2021. doi:10.1053/j.gastro.2021.03.043 34. Ruiz-González A, Utrillo L, Bielsa S, Falguera M, Porcel JM. The Diagnostic Value of Serum C-Reactive Protein for Identifying Pneumonia in Hospitalized Patients with Acute Respiratory Symptoms. Journal of Biomarkers. 2016;2016. doi:10.1155/2016/2198745

35. Magro B, Zuccaro V, Novelli L, et al. Predicting in-hospital mortality from Coronavirus Disease 2019: A simple validated 
app for clinical use. PLoS ONE. 2021;16(1). doi:10.1371/journal.pone.0245281

36. Tsui PT, Kwok ML, Yuen H, Lai ST. Severe acute respiratory syndrome: Clinical outcome and prognostic correlates. Emerging Infectious Diseases. 2003;9(9):1064-1069. doi:10.3201/eid0909.030362

37. Bartz D, Chitnis T, Kaiser UB, et al. Clinical Advances in Sex- and GenderInformed Medicine to Improve the Health of
All: A Review. JAMA Internal Medicine. 2020;180(4):574-583.

doi:10.1001/jamainternmed.2019.7194

38. Raimondi F, Novelli L, Ghirardi A, et al. Covid-19 and gender: lower rate but same mortality of severe disease in women - an observational study. BMC Pulmonary Medicine. 2021;21(1). doi:10.1186/s12890021-01455-0 


\section{SUPPLEMENTARY MATERIALS}

Supplementary Table 1: STROBE check-list

Supplementary Table 2: AST, ALT, CRP and LDH values at day 1 and at day 7 according to the presence of respiratory failure at admission

\begin{tabular}{|c|c|c|c|c|c|c|}
\hline & \multicolumn{2}{|c|}{ Day 1} & & \multicolumn{2}{|c|}{ Day 7} & \multirow[b]{2}{*}{ p-value } \\
\hline & $\begin{array}{l}\text { Respiratory } \\
\text { failure }\end{array}$ & $\begin{array}{l}N O \\
\text { respiratory } \\
\text { failure }\end{array}$ & p-value & $\begin{array}{l}\text { Respiratory } \\
\text { failure }\end{array}$ & $\begin{array}{l}N O \\
\text { respiratory } \\
\text { failure }\end{array}$ & \\
\hline $\begin{array}{c}\mathrm{CRP} \\
\text { median }\end{array}$ & $13(4-17)$ & $4(2-10)$ & $<0.001$ & $12,5(5-23)$ & $16(6-42,25)$ & 0.002 \\
\hline $\begin{array}{c}\text { AST } \\
\text { median }\end{array}$ & $\begin{array}{c}53(33,5- \\
73,75)\end{array}$ & $\begin{array}{c}31,5(24- \\
55,5)\end{array}$ & $<0.001$ & $47(29-67,5)$ & $33(22-55,5)$ & 0.001 \\
\hline $\begin{array}{c}\text { ALT } \\
\text { median }\end{array}$ & $39(26-60,75)$ & $30(22-52)$ & 0.03 & $\begin{array}{l}45(28- \\
73,75)\end{array}$ & $37(25-69,5)$ & 0.09 \\
\hline $\begin{array}{c}\text { LDH } \\
\text { median }\end{array}$ & $\begin{array}{c}400(300- \\
512,75)\end{array}$ & $\begin{array}{c}288(234,5- \\
387,5)\end{array}$ & $<0.001$ & $\begin{array}{c}384(296,5- \\
517,5)\end{array}$ & $\begin{array}{c}266(223- \\
345,5)\end{array}$ & $<0.001$ \\
\hline
\end{tabular}

Supplementary Table 3: Prevalence of transaminases elevation at day 1 and at day 7, in patients with and without respiratory failure at admission

\begin{tabular}{|c|c|c|c|c|c|c|c|c|c|}
\hline & \multicolumn{3}{|c|}{ Overall } & \multicolumn{3}{|c|}{ Respiratory failure } & \multicolumn{3}{|c|}{ NO Respiratory failure } \\
\hline & $\begin{array}{c}\text { Normal } \\
\mathrm{n}(\%)\end{array}$ & $\begin{array}{l}<2 \mathrm{~N} \\
\mathrm{n}(\%)\end{array}$ & $\begin{array}{l}>2 \mathrm{~N} \\
\mathrm{n}(\%)\end{array}$ & $\begin{array}{c}\text { Normal } \\
\mathrm{n}(\%)\end{array}$ & $\begin{array}{l}<2 \mathrm{~N} \\
\mathrm{n}(\%)\end{array}$ & $\begin{array}{l}>2 \mathrm{~N} \\
\mathrm{n}(\%)\end{array}$ & $\begin{array}{c}\text { Normal } \\
\mathrm{n}(\%)\end{array}$ & $\begin{array}{l}<2 \mathrm{~N} \\
\mathrm{n}(\%)\end{array}$ & $\begin{array}{l}>2 \mathrm{~N} \\
\mathrm{n}(\%)\end{array}$ \\
\hline $\begin{array}{c}\text { AST U/L } \\
\text { day1 }\end{array}$ & $\begin{array}{l}158 / 321 \\
(49.2 \%)\end{array}$ & $\begin{array}{l}113 / 321 \\
(35,2 \%)\end{array}$ & $\begin{array}{c}50 / 321 \\
(15,6 \%)\end{array}$ & $\begin{array}{c}43 / 131 \\
(32.8 \%)\end{array}$ & $\begin{array}{c}68 / 131 \\
(51.9 \%)\end{array}$ & $\begin{array}{c}20 / 131 \\
(15.3 \%)\end{array}$ & $\begin{array}{l}115 / 183 \\
(62.8 \%)\end{array}$ & $\begin{array}{c}41 / 183 \\
(22.4 \%)\end{array}$ & $\begin{array}{c}27 / 183 \\
(14.8 \%)\end{array}$ \\
\hline $\begin{array}{c}\text { ALT U/L } \\
\text { day1 }\end{array}$ & $\begin{array}{l}134 / 292 \\
(45.9 \%)\end{array}$ & $\begin{array}{l}105 / 292 \\
(35.9 \%)\end{array}$ & $\begin{array}{c}53 / 292 \\
(18,2 \%)\end{array}$ & $\begin{array}{c}63 / 135 \\
(46.7 \%)\end{array}$ & $\begin{array}{c}49 / 135 \\
(36.3 \%)\end{array}$ & $\begin{array}{l}23 / 135 \\
(17 \%)\end{array}$ & $\begin{array}{c}71 / 157 \\
(45.2 \%)\end{array}$ & $\begin{array}{c}56 / 157 \\
(35.7 \%)\end{array}$ & $\begin{array}{c}30 / 157 \\
(19,1 \%)\end{array}$ \\
\hline $\begin{array}{c}\text { AST U/L } \\
\text { day7 }\end{array}$ & $\begin{array}{l}151 / 290 \\
(52.1 \%)\end{array}$ & $\begin{array}{c}97 / 290 \\
(33.4 \%)\end{array}$ & $\begin{array}{c}42 / 290 \\
(14,5 \%)\end{array}$ & $\begin{array}{c}50 / 123 \\
(40.6 \%)\end{array}$ & $\begin{array}{c}51 / 123 \\
(41.5 \%)\end{array}$ & $\begin{array}{c}22 / 123 \\
(17,9 \%)\end{array}$ & $\begin{array}{l}101 / 167 \\
(60.5 \%)\end{array}$ & $\begin{array}{c}46 / 167 \\
(27.5 \%)\end{array}$ & $\begin{array}{l}20 / 167 \\
(12 \%)\end{array}$ \\
\hline $\begin{array}{l}\text { ALT U/L } \\
\text { day7 }\end{array}$ & $\begin{array}{l}139 / 290 \\
(47.9 \%)\end{array}$ & $\begin{array}{c}84 / 290 \\
(29.0 \%)\end{array}$ & $\begin{array}{c}67 / 290 \\
(23,1 \%)\end{array}$ & $\begin{array}{c}50 / 123 \\
(40.6 \%)\end{array}$ & $\begin{array}{c}44 / 123 \\
(35.8 \%)\end{array}$ & $\begin{array}{c}29 / 123 \\
(23,6 \%)\end{array}$ & $\begin{array}{c}89 / 167 \\
(53.3 \%)\end{array}$ & $\begin{array}{c}40 / 167 \\
(23.9 \%)\end{array}$ & $\begin{array}{c}38 / 167 \\
(22,8 \%)\end{array}$ \\
\hline
\end{tabular}


Supplementary Table 4: Clinical features of patients with pre-existing liver disease

$\begin{array}{cc}\text { PATIENTS WITH CHRONIC LIVER DISEASE }(\boldsymbol{n}) & \mathbf{1 2} \\ -\quad \text { Cirrhosis } & \mathbf{4} \\ -\quad \text { Chronic Viral Hepatitis } & \mathbf{3} \\ -\quad \text { NAFLD/NASH } & \mathbf{5} \\ \text { Age median } & 64(56-74) \\ \text { Female }\{n(\%)\} & 2(16.7)\end{array}$

\section{Comorbidities}

$\begin{array}{lc}\text { Hypertension }\{\boldsymbol{n}(\boldsymbol{\%})\} & 9(75.0) \\ \text { Diabetes }\{\boldsymbol{n}(\boldsymbol{\%})\} & 5(41,7) \\ \text { Obesity }\{\boldsymbol{n}(\boldsymbol{\eta})\} & 3(25,0) \\ \text { Cardiological comorbidities }\{\boldsymbol{n}(\boldsymbol{\%})\} & 2(16.7) \\ \text { Oncological comorbidities }\{\boldsymbol{n}(\boldsymbol{\%})\} & 1(8.3) \\ \text { Pneumological comorbidities }\{\boldsymbol{n}(\boldsymbol{\%})\} & 1(8.3) \\ \text { Nephrological comorbidities }\{\boldsymbol{n}(\boldsymbol{\%})\} & 2(16.7) \\ \text { Reumathological comorbidities }\{\boldsymbol{n}(\boldsymbol{\%})\} & 0(0)\end{array}$

\section{Onset Symptoms}

Respiratory Failure at admission \{n (\%)\} 9 (75.0)

Fever $\{n(\%)\}$

Gastrointestinal symptoms $\{n(\%)\}$

Neurological symptoms $\{n(\%)\}$

\section{Ventilation at admission}

No ventilation

Nasal cannula/Venturi Mask

Reservoir Mask

CPAP

Laboratory findings

AST at admission \{median (IQR)\} U/L

AST at day 7 \{median (IQR)\} U/L

ALT at admission \{median (IQR)\} U/L

ALT at day 7 \{median (IQR)\} U/L

CRP at admission \{median (IQR)\} $\mathrm{mg} / \mathrm{dl}$

PCR at day 7 \{median (IQR)\} mg/dl

LDH at admission \{median (IQR)\} U/L

LDH at day 7 \{median (IQR)\} U/L
$3(25.0)$

$5(41.7)$

$4(33.3)$

$0(0)$

45 (27-63.5)

$40(25-58)$

$33(24-54)$

$41(26-68)$

$7(2.3-14)$

$12(4-22.2)$

$327(256-462)$

$302(242-413)$ 